\title{
Random Amplified Polymorphic DNA analysis provides rapid differentiation among isolates of the fish pathogen Flavobacterium psychrophilum and among Flavobacterium species
}

\author{
Chehid Chakroun', Maria C. Urdaci ${ }^{2}$, Didier Faure ${ }^{2}$, Francine Grimont ${ }^{3}$, \\ Jean-François Bernardet ${ }^{1, *}$
}

${ }^{1}$ Unité de Virologie et d'Immunologie Moléculaires, Institut National de la Recherche Agronomique, F-78352 Jouy-en-Josas Cedex, France

${ }^{2}$ Laboratoire de Microbiologie, Ecole Nationale des Ingénieurs des Travaux Agricoles de Bordeaux, 1 cours du Général de Gaulle, BP 201, F-33175 Gradignan Cedex, France

${ }^{3}$ Unité des Entérobactéries, Unité 389 de l'Institut National de la Santé et de la Recherche Médicale, Institut Pasteur, F-75724 Paris Cedex 15, France

\begin{abstract}
Flavobacterium psychrophilum is the agent of cold-water disease and rainbow trout fry syndrome in salmonid fish. Originally isolated in North America only, the bacterium is now also responsible for severe mortalities in many salmonid hatcheries in Europe, as well as in Japan, Chile and Tasmania. The random amplified polymorphic DNA (RAPD) technique was used to analyze the genetic diversity among a collection of $177 F$. psychrophilum strains isolated from different fish species and in different geographical areas. Forty 10 -mer primers were tested and 5 of them were selected for further analysis of the bacterial DNAs. The primers OPH 06, OPH 08, OPG 08, OPG 14, and OPG 16 generated several reproducible profiles during a preliminary screening of the whole collection of strains. Based on these results, the polymerase chain reaction (PCR) products of a selection of 60 bacterial DNAs were submitted to slow agarose gel electrophoresis for numerical analysis of the DNA fingerprintings. No correlation occurred between the combined RAPD profiles of the primers and the geographical origin of the strains, while some profiles were clearly associated with the fish species from which the strains were isolated. Another primer, OPG 10, yielded a unique RAPD profile common to all F. psychrophilum strains whereas the 9 other valid Flavobacterium species, several of which coexist in freshwater environments and may also be isolated from fish, displayed other profiles. Thus, depending on the primer used, both the typing of $F$. psychrophilum strains for epidemiology studies as well as the identification of this fish pathogen and its differentiation from related bacterial species could be achieved by using RAPD
\end{abstract}

KEY WORDS: Flavobacterium psychrophilum - Flavobacterium spp. C Cold-water disease - Rainbow trout fry syndrome $\cdot$ RAPD $\cdot$ Epidemiology

\section{INTRODUCTION}

Flavobacterium psychrophilum (Bernardet et al. 1996) (syn. Cytophaga psychrophila, Flexibacter psychrophilus), the causative agent of cold-water disease and rainbow trout fry syndrome, was originally isolated from coho salmon Oncorhynchus kisutch in Washing-

-Addressee for correspondence. E-mãil: jfb@biotec.jouy.inra.fr ton state, USA, in 1948 (Borg 1960), and later found in chinook salmon Oncorhynchus tshawytscha from the same area (Anderson \& Conroy 1969). In recent years, cold-water disease has also caused serious problems among rainbow trout juveniles reared in the Pacific Northwest area (R. A. Holt pers. comm.). Since the mid-eighties, the same bacterium has been responsible for high losses in rainbow trout Oncorhynchus mykiss fry in many European hatcheries (Weis 1987 , 
Bernardet et al. 1988, Lorenzen et al. 1991, Austin 1992, Sarti et al. 1992, Toranzo \& Barja 1993, Wiklund et al. 1994). In Europe, it was also isolated from European eel Anguilla anguilla, carp Cyprinus carpio, tench Tinca tinca and crucian carp Carassius carassius (Lehmann et al. 1991). In Japan, the disease has become a concern in rainbow trout, coho salmon and ayu Plecoglossus altivelis farms (Wakabayashi et al. 1994). Recently this bacterium was also isolated in Chile from rainbow trout fry (Bustos et al. 1995) and in Tasmania, Australia, from Atlantic salmon (Schmidtke \& Carson 1995). An efficient typing method would allow an accurate comparison of strains retrieved from widely different origins and would benefit epidemiology studies of the disease.

Several other Flavobacterium species may be isolated from diseased freshwater fish (Bernardet et al. 1996). Some of them (Flavobacterium columnare, $F$. branchiophilum, F. johnsoniae) have been demonstrated to be pathogenic, at least in certain circumstances, while the pathogenicity of other species $[F$. hydatis (syn. Cytophaga aquatilis), F. succinicans] has not been established. As most Flavobacterium species are relatively fastidious and inert in many biochemical tests, the identification of $F$. psychrophilum is timeconsuming and confusion with other Flavobacterium species may occur. A rapid and specific identification method would greatly improve the diagnosis of the conditions caused by F. psychrophilum.

In this study, we demonstrate that both a rapid and clear differentiation of Flavobacterium psychrophilum from related bacterial species, as well as an efficient intra-specific typing of $F$. psychrophilum strains, can be achieved by using Random Amplified Polymorphic DNA (RAPD) (Williams et al. 1990), depending on the primer used.

\section{MATERIALS AND METHODS}

Bacterial strains and growth conditions. A total of 177 Flavobacterium psychrophilum strains isolated over the years in different geographical areas 159 strains from France, 6 from Spain, 4 from Sweden, 22 from Denmark, 9 from Germany, 19 from Switzerland, 6 from the United Kingdom, 1 from Norway, 1 from Finland, 28 from the USA, 1 from Canada, 6 from Chile, 10 from Japan and 5 from Tasmania) were included in this study. This collection of strains was screened (see details below) and 60 of them, listed in Table 1, were included in the final study. All F. psychrophilum strains were grown at $18^{\circ} \mathrm{C}$ on Anacker and Ordal's agar (tryptone, $0.05 \%$; yeast extract, $0.05 \%$; beef extract, $0.02 \%$; and sodium acetate, $0.02 \% ; \mathrm{pH} 7.2$ to 7.4 ) (Anacker \& Ordal 1955) supplemented to $0.5 \%$ tryptone. Representative strains of the 9 other valid Flavobacterium species were included in this study and are listed in Table 2. They were grown on the same medium at $22^{\circ} \mathrm{C}$.

Preparation of DNA. Each strain was collected on the agar plate, suspended in $0.9 \%$ saline and centrifuged. The pellet was resuspended in an equal volume $(200 \mu$ l) of TES $(50 \mathrm{mM}$ Tris buffer, $1 \mathrm{mM}$ EDTA, $8.56 \%$ saccharose) $\mathrm{pH} 8.00$ containing $20 \mu \mathrm{g}$ of lysozyme (Sochal, Levallois-Perret, France), and incubated at $37^{\circ} \mathrm{C}$ for $1 \mathrm{~h}$. Fifty $\mu \mathrm{l}$ of $20 \%$ sodium dodecyl sulphate (SDS) was added to the mixture. The solution was treated 3 times with a mixture of phenol, chloroform and isoamyl alcohol $(25 / 24 / 1 ; v / v / v)$ and once with chloroform-isoamyl alcohol $(24 / 1 ; v / v)$. The DNA was precipitated by an equal volume of isopropanol, dried under vacuum, and dissolved in $200 \mu \mathrm{l}$ of sterile Miiili-Q water containing $10 \mu \mathrm{g}$ of RNase (ribonuclease I-A from bovine pancreas, Sigma Chemical Co., St. Louis, MO, USA) and incubated at $37^{\circ} \mathrm{C}$ for $15 \mathrm{~min}$. All DNA samples were stored at $-20^{\circ} \mathrm{C}$.

Amplification conditions. Two kits of 20 arbitrary $10-$ mer primers each (OPG and OPH, Bioprobe, Montrevilsous-bois, France) were evaluated for random amplification of DNAs. The technique used in this study was adapted from Meunier \& Grimont (1993). Briefly, $25 \mu \mathrm{l}$ of reaction mixture containing 25 to $50 \mathrm{ng}$ of genomic DNA, 5 pmol of primer, $50 \mu \mathrm{M}$ of each dNTP (Appligene, Illkirch, France), $0.6 \mathrm{U}$ of Taq DNA polymerase (reference $120187 \mathrm{C}$, Appligene) and $2.5 \mu$ l of $10 \times$ polymerase chain reaction (PCR) reaction buffer was overlaid with mineral oil. The amplification reaction was performed in a DNA thermal cycler (Own E Hybaid, Teddington, England) programmed for 45 cycles of $30 \mathrm{~s}$ at $94^{\circ} \mathrm{C}$ (denaturing of DNA), 1 min at $36^{\circ} \mathrm{C}$ (primer annealing) and 1 min at $72^{\circ} \mathrm{C}$ (polymerization), with 5 min initial denaturation at $95^{\circ} \mathrm{C}$ and 10 min final extension at $72^{\circ} \mathrm{C}$. In order to test the reproducibility of the technique, DNA amplification experiments were repeated 3 times under the same conditions. A negative control, containing no template DNA, was included in each experiment in order to detect any contaminating DNA.

Electrophoresis conditions. Gel electrophoresis was carried out by loading $25 \mu \mathrm{l}$ samples of all 177 amplification products in submerged horizontal $1 \%$ agarose gel (Bioprobe). Gels were run for $1 \mathrm{~h}$ at $10 \mathrm{~V} \mathrm{~cm}^{-1}$ in Tris-borate buffer $(89 \mathrm{mM}$ Tris-base, $89 \mathrm{mM}$ boric acid, 2 mM EDTA) without cooling. Amplification products were visualized after ethidium bromide staining and photographed on a UV light transilluminator

The amplification products of 60 selected strains (see details below) generated by the primers OPH 06 and $\mathrm{OPH} 08$ were also compared using special conditions of electrophoresis $\left(3 \mathrm{~V} \mathrm{~cm}^{-1}\right.$ for $8 \mathrm{~h}$ ), improving the resolution of the patterns for computer analysis. 
Table 1. Flavobacterium psychrophilum. Strains included in the computer analysis of their RAPD fingerprints generated by the primers $\mathrm{OPH} 06$ and $\mathrm{OPH} 08$

\begin{tabular}{|c|c|c|c|c|}
\hline Strain & \multicolumn{2}{|l|}{ Origin } & Strain & Origin \\
\hline JIP 02/86 & \multirow{2}{*}{\multicolumn{2}{|c|}{$\begin{array}{l}\text { Rainbow trout Oncorbynchus mykiss, } \\
\text { kidney, Picardie, France, } 1986\end{array}$}} & OSU SRCO5-90 & Coho salmon, kidney, Oregon, USA, 1990 \\
\hline JIP P02/88 & \multirow{2}{*}{\multicolumn{2}{|c|}{$\begin{array}{l}\text { Rainbow trout, kidney, Picardie, } \\
\text { France, } 1988\end{array}$}} & OSU PCP1.1 & Coho salmon, kıdney, Oregon, USA, 1989 \\
\hline & & & OSU NHCO4-90 & Coho salmon, kidney, Oregon, USA, 1990 \\
\hline LVDL $1829-91$ & \multicolumn{2}{|c|}{ Rainbow trout, liver, Navarra, Spain, 1991} & OSU CO26.BR.2.1 & Coho salmon, brain, Oregon, USA, 1990 \\
\hline LVDL $3077-91$ & \multicolumn{2}{|c|}{$\begin{array}{l}\text { Rainbow trout, spleen, Navarra, Span, } \\
1991\end{array}$} & $\begin{array}{l}\text { OSU BC } 3-81 \\
\text { OSU NHCo2-90 }\end{array}$ & $\begin{array}{l}\text { Coho salmon, kidney, Oregon, USA, } 1981 \\
\text { Coho salmon, kidney, Oregon, USA, } 1990\end{array}$ \\
\hline ISTAB AC 15/I.1 & \multicolumn{2}{|c|}{$\begin{array}{l}\text { Rainbow trout, spleen, Navarra, Spain, } \\
1996\end{array}$} & $\begin{array}{l}\text { OSU Ch8-80 } \\
\text { OSU TM3.1 }\end{array}$ & $\begin{array}{l}\text { Coho salmon, Oregon, USA, } 1980 \\
\text { Coho salmon, kidney, Oregon, USA, } 1989\end{array}$ \\
\hline SVA $31-88$ & \multicolumn{2}{|c|}{ Rainbow trout, muscle, Sweden, 1988} & FPC 828 & Coho salmon, kidney, Miyagi, Japan, 1990 \\
\hline SVA $120-89$ & \multicolumn{2}{|c|}{ Rainbow trout, muscle, Sweden, 1989} & FPC 829 & Coho salmon, kidney, Miyagi, Japan, 1990 \\
\hline SVS $911209-2$ & \multicolumn{2}{|c|}{$\begin{array}{l}\text { Rainbow trout, spleen, Brons, Denmark, } \\
1990\end{array}$} & FPC 830 & Coho salmon, kidney, Miyagi, Japan, 1990 \\
\hline SVS 911209-1 & \multirow{2}{*}{\multicolumn{2}{|c|}{$\begin{array}{l}\text { Rainbow trout, spleen, Trehoje, Denmark, } \\
1990\end{array}$}} & FPC 831 & $\begin{array}{l}\text { Coho salmon, peduncle lesion, Iwate, } \\
\text { Japan, } 1990\end{array}$ \\
\hline करण & & & OSU SRChF8-81 & Chinook salmon Oncorhyncus \\
\hline SVS $910614-3$ & \multirow{2}{*}{\multicolumn{2}{|c|}{$\begin{array}{l}\text { Rainbow trout, skin lesion, Bregnholm, } \\
\text { Denmark, } 1991\end{array}$}} & & tshawytscha, kidney, Oregon, USA, 1981 \\
\hline SVS $911009-3$ & & & DPIF $91 / 4043-4$ & $\begin{array}{l}\text { Atlantic salmon Salmo salar, eroded fin, } \\
\text { Tasmania, Australia, } 1991\end{array}$ \\
\hline DIFR 880406 & \multicolumn{2}{|c|}{$\begin{array}{l}\text { Rainbow trout, skin lesion, Rindsholm, } \\
\text { Denmark, } 1991\end{array}$} & DPIF $91 / 4043-8$ & $\begin{array}{l}\text { Atlantic salmon, eroded fin, Tasmania, } \\
\text { Australia, } 1991\end{array}$ \\
\hline DIFR 900406 & \multicolumn{2}{|c|}{ Rainbow trout, kidney, Denmark, 1990} & DPIF $91 / 4043-13$ & Atlantic salmon, eroded fin, Tasmania, \\
\hline LFNW $123 / 89$ & \multirow{2}{*}{\multicolumn{2}{|c|}{$\begin{array}{l}\text { Rainbow trout, skin lesion, Nordrhein- } \\
\text { Westfalen, Germany, } 1989\end{array}$}} & & \\
\hline & & & DPIF $91 / 4043-14$ & Atlantic salmon, eroded fin, Tasmania, \\
\hline IVP CH7/93 & \multicolumn{2}{|c|}{ Rainbow trout, Bern, Switzerland, 1993} & & \\
\hline IVP $\mathrm{CH} 3 / 94$ & \multicolumn{2}{|c|}{ Rainbow trout, Bern, Switzerland, 1994} & DPIF 91/4043-17 & $\begin{array}{l}\text { Atlantic salmon, eroded fin, Tasmania, } \\
\text { Australia } 1991\end{array}$ \\
\hline $\begin{array}{l}\text { IVP CH1/93 } \\
\text { OSU Ana9.1.1 }\end{array}$ & \multicolumn{2}{|c|}{ Rainbow trout, Bern, Switzerland, 1993} & OSU AD10.1.1 & $\begin{array}{l}\text { Australla, } 1991 \\
\text { Atlantic salmon, kidney, Oregon, USA, } \\
1990\end{array}$ \\
\hline OSU $90-66 \mathrm{~A}$ & \multicolumn{2}{|c|}{ Rainbow trout, spleen, Idaho, USA, 1990} & osu CCC6-86 & Cutthroat trout Salmo clarki, Oregon, \\
\hline UCD 004-95 & \multicolumn{2}{|c|}{ Rainbow trout, kidney, Idaho, USA, 1995} & & \\
\hline UCD $95-7$ & \multicolumn{2}{|c|}{$\begin{array}{l}\text { Rainbow trout, kidney, California, USA, } \\
1995\end{array}$} & FPC 839 & $\begin{array}{l}\text { Ayu Plecoglossus altivelis, kidney, } \\
\text { Tokushima, Japan, } 1987\end{array}$ \\
\hline UCD $146-95$ & \multicolumn{2}{|c|}{ Rainbow trout, kidney, Idaho, USA, 1995} & FPC 837 & Ayu, kidney, Iwate, Japan, 1988 \\
\hline UCD R3/8/95 & \multicolumn{2}{|c|}{ Rainbow trout, USA, 1995} & FPC 838 & Ayu, liver, Tokushima, Japan, 1988 \\
\hline FPC 813 & \multicolumn{2}{|c|}{$\begin{array}{l}\text { Rainbow trout, kidney, Tokyo, Japan, } \\
1992\end{array}$} & FPC 840 & Ayu, kidney, Tokushima, Japan, 1987 \\
\hline OSU RbS6-82 & \multirow{2}{*}{\multicolumn{2}{|c|}{$\begin{array}{l}\text { Steelhead trout Oncorhynchus mykiss, } \\
\text { kidney, Oregon, USA, } 1982\end{array}$}} & LVDI $5 / \mathrm{I}$ & $\begin{array}{l}\text { Carp Cyprinus carpio, gills, Centre, } \\
\text { France, } 1992\end{array}$ \\
\hline NCIMB $1947^{\top}$ & & & LFNW $16 / 90$ & $\begin{array}{l}\text { Carp, spleen, Nordrhein-Westfalen, } \\
\text { Germany } 1990\end{array}$ \\
\hline Notivis 134 & kidney, Washington, & A & LFNW $25 / 90$ & $\begin{array}{l}\text { Germany, } 1990 \\
\text { Tench Tinca tinca, kidney, Nordrhein- }\end{array}$ \\
\hline NCIMB 2282 & Coho salmon, kidney, & ashington, USA, & & \\
\hline OSU SH3-81 & $\begin{array}{l}1948 \\
\text { Coho salmon, kidne }\end{array}$ & & LVDJ XP189 & $\begin{array}{l}\text { Tench, kidney, Franche-Comté, France, } \\
1992\end{array}$ \\
\hline OSU THCO2-90 & Coho salmon, kidney, & egon, USA, 1990 & LVDJ D 2172 & Tench, Franche-Comté, France, 1995 \\
\hline OSU THCO4-90 & Coho salmon, kidney, & regon, USA, 1990 & LFNW 131/89 & $\begin{array}{l}\text { European eel Anguilla anguilla, kidney, } \\
\text { Nordrhein-Westfalen, Germany, } 1989\end{array}$ \\
\hline & & & & \\
\hline $\begin{array}{l}\text { JrP: Culture Colle } \\
\text { ogie et Immunolo } \\
\text { tut National de la }\end{array}$ & $\begin{array}{l}\text { tion of Unité de Virol- } \\
\text { ie Moléculaires, Insti- } \\
\text { Recherche Agronom- }\end{array}$ & $\begin{array}{l}\text { DIFR: strains proy } \\
\text { Danish Institute f } \\
\text { Frederiksberg, De }\end{array}$ & $\begin{array}{l}\text { by I. Dalsgaard, } \\
\text { sheries Research, } \\
k\end{array}$ & $\begin{array}{l}\text { FPC: strains provided by H. Wakabayashi, } \\
\text { Laboratory of Aquaculture Biology, Uni- } \\
\text { versity of Tokyo, Japan }\end{array}$ \\
\hline ique, Jouy-en-Jos & France & & & NCIMB: National Collection of Industrial \\
\hline $\begin{array}{l}\text { LVDL: strains prov } \\
\text { Laboratoire Vété }\end{array}$ & $\begin{array}{l}\text { ded by P. Nougayrède, } \\
\text { naire Départemental }\end{array}$ & $\begin{array}{l}\text { desanstalt für Fisc } \\
\text { falen, Kirchhunder }\end{array}$ & $\begin{array}{l}\text { Nordrhein-West- } \\
\text { baum, Germany }\end{array}$ & $\begin{array}{l}\text { and Marine Bacteria, Aberdeen, United } \\
\text { Kingdom }\end{array}$ \\
\hline des Landes, Mont & 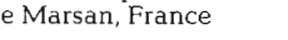 & & & DPIF: strains provided by J. Carson, De- \\
\hline $\begin{array}{l}\text { ISTAB: Culture } \\
\text { Supérieur de Tecl } \\
\text { Biotechnologie, B }\end{array}$ & $\begin{array}{l}\text { Dollection of Institut } \\
\text { hologie Alimentaire et } \\
\text { deaux, France }\end{array}$ & $\begin{array}{l}\text { IVP: strains provid } \\
\text { of Veterinary Path } \\
\text { land }\end{array}$ & $\begin{array}{l}\text { T. Wahli, Institute } \\
\text { Y, Berne, Switzer- }\end{array}$ & $\begin{array}{l}\text { partment of Primary Industry and Fish- } \\
\text { eries, Kings Meadows, Tasmania, Aus- } \\
\text { tralia }\end{array}$ \\
\hline $\begin{array}{l}\text { SVA: strain prov } \\
\text { Statens Veterinärr } \\
\text { sala, Sweden }\end{array}$ & $\begin{array}{l}\text { led by A. Hellström, } \\
\text { edicinska Ansalt, Upp- }\end{array}$ & $\begin{array}{l}\text { OSU: strains provi } \\
\text { R. A. Holt, Oregon } \\
\text { vallis, USA }\end{array}$ & $\begin{array}{l}\text { M. Whipple and } \\
\text { University, Cor- }\end{array}$ & $\begin{array}{l}\text { LVDI: strain provided by J.-L. Bind, } \\
\text { Laboratoire Vétérinaire Départemental } \\
\text { d'Indre-et-Loire, Tours, France }\end{array}$ \\
\hline $\begin{array}{l}\text { SVS: strains pro } \\
\text { Statens Veterinae } \\
\text { Arhus, Denmark }\end{array}$ & $\begin{array}{l}\text { ded by E. Lorenzen, } \\
\text { e Serumlaboratorium, }\end{array}$ & $\begin{array}{l}\text { UCD: strains provi } \\
\text { versity of Californi }\end{array}$ & $\begin{array}{l}\text { by R. Hedrick, Uni- } \\
\text { avis, USA }\end{array}$ & $\begin{array}{l}\text { LVDJ: strains provided by } M \text {. Morand, } \\
\text { Laboratoire Vétérinaire Départemental } \\
\text { du Jura, Lons-le-Saunier, France }\end{array}$ \\
\hline
\end{tabular}


Table 2. Flavobacterium strains and species included in the random amplification using the primer OPG 10

\begin{tabular}{|c|c|c|c|}
\hline Species & Strain & \multicolumn{2}{|l|}{ Origin } \\
\hline F. aquatile & LMG $4008^{\mathrm{T}}$ & \multicolumn{2}{|l|}{ Deep well. Kent, England } \\
\hline F. branchiophilum & $\operatorname{ATCC~} 35035^{\mathrm{T}}$ & \multicolumn{2}{|c|}{ Diseased gills of yamame Oncorhynchus masou, Gumma, Japan } \\
\hline F. branchiophilum & FL-15 & \multicolumn{2}{|c|}{ Diseased gills of sheatfish Silurus glanis, Hungary } \\
\hline F. columnare & JIP $39 / 87$ & \multicolumn{2}{|c|}{ Skin lesion of black bullhead Ictalurus melas, Ile-de-France, France } \\
\hline F. columnare & FPC EK28 & \multicolumn{2}{|c|}{ Gill lesions of Japanese eel Anguilla japonica, Shizuoka, Japan } \\
\hline F. columnare & OSU DD3-69 & \multicolumn{2}{|c|}{ Gill lesions of chinook salmon Oncorhynchus tshawytscha, Oregon, USA } \\
\hline F. flevense & $\operatorname{DSM} 1076^{\mathrm{T}}$ & \multicolumn{2}{|c|}{ Lake Ijssel, The Netherlands } \\
\hline F. hydatis & DSM $2063^{T}$ & \multicolumn{2}{|c|}{ Gills of diseased salmon, Michigan, USA } \\
\hline F. johnsoniae & DSM $2064^{\mathrm{T}}$ & \multicolumn{2}{|c|}{ Soil or mud, Rothamsted or Cambridge, England } \\
\hline F. johnsoniae & ATCC 29585 & \multicolumn{2}{|c|}{ Diseased freshwater fish, Manitoba, Canada } \\
\hline F pectinovorum & NCIMB $9059^{\mathrm{T}}$ & \multicolumn{2}{|c|}{ Soil, England } \\
\hline F. psychrophilum & NCIMB $1947^{\mathrm{T}}$ & \multicolumn{2}{|c|}{ Kidney of diseased coho salmon Oncorhynchus kisutch, Washington, USA } \\
\hline F. psychrophilum & JIP P02/88 & \multicolumn{2}{|c|}{ Kidney of rainbow trout Oncorhynchus mykiss, Picardie, France } \\
\hline F. psychrophilum & LVDJ XP 189 & \multicolumn{2}{|c|}{ Kidney of tench Tinca tinca, Franche-Comté, France } \\
\hline F. psychrophilum & OSU CCC6-86 & \multicolumn{2}{|c|}{ Cutthroat trout Salmo clarki, Oregon, USA } \\
\hline F. psychrophilum & FPC 839 & \multicolumn{2}{|c|}{ Kidney of ayu Plecoglossus altivelis, Tokushima, Japan } \\
\hline F. psychrophilum & OSU RbS6-82 & \multicolumn{2}{|c|}{ Kidney of steelhead troüt Onconhynchus mykiss, Oregon, USA } \\
\hline F. saccharophilum & $\mathrm{NCIMB} 2072^{\top}$ & \multicolumn{2}{|c|}{ River Wey, Surrey, England } \\
\hline F. succinicans & NCIMB $2277^{\mathrm{T}}$ & \multicolumn{2}{|c|}{ Eroded fin of chinook salmon, Washington, USA } \\
\hline F. succinicans & NCIMB 2278 & \multicolumn{2}{|c|}{ Lesion of chinook salmon, Snake River, Idaho, USA } \\
\hline \multicolumn{4}{|l|}{ Strain sources: } \\
\hline $\begin{array}{l}\text { LMG: Culture Collec } \\
\text { rium voor Microbio } \\
\text { Ghent, Ghent, Belgru }\end{array}$ & $\begin{array}{l}\text { Une Laborato- } \\
\text { University of }\end{array}$ & $\begin{array}{l}\text { JIP: Culture Collection of the Unité de } \\
\text { Virologie et Immunologie Moléculaires, } \\
\text { Institut National de la Recherche } \\
\text { Agronomique, Jouy-en-Josas, France }\end{array}$ & $\begin{array}{l}\text { NCIMB: National Collection of Industrial } \\
\text { and Marine Bacteria, Aberdeen, United } \\
\text { Kingdom }\end{array}$ \\
\hline $\begin{array}{l}\text { ATCC: American T } \\
\text { tion, Rockville, Mary }\end{array}$ & Culture Collec- & \multirow{2}{*}{$\begin{array}{l}\text { Agronomique, Jouy-en-Josas, France } \\
\text { OSU: strains provided by M. Whipple } \\
\text { and R. A. Holt, Oregon State University, } \\
\text { Corvallis, USA }\end{array}$} & \multirow{3}{*}{$\begin{array}{l}\text { LVDJ: strain provided by M. Morand, } \\
\text { Laboratoire Vétérinaire Départemental } \\
\text { du Jura, Lons-le-Saunier, France }\end{array}$} \\
\hline $\begin{array}{l}\text { FPC EK } 28, \text { FPC } 839 \text { a } \\
\text { vided by } \mathrm{H} \text {. Wakaba }\end{array}$ & $\begin{array}{l}-15 \text { : strains pro- } \\
\text { i, Laboratory of }\end{array}$ & & \\
\hline $\begin{array}{l}\text { Aquaculture Biology, } \\
\text { eries, University of To }\end{array}$ & $\begin{array}{l}\text { artment of Fish- } \\
\text { Tokyo, Japan }\end{array}$ & $\begin{array}{l}\text { DSM: Deutsche Sammlung von Mikroor- } \\
\text { ganismen, Braunschweig, Germany }\end{array}$ & \\
\hline
\end{tabular}

Computer-assisted analysis of the DNA fingerprints. Each gel, consisting of 10 lanes of amplification products and 3 lanes of molecular weight marker (123 base pairs, bp; Gibco BRL, USA), was photographed using a Polaroid film type 665 (Polaroid, Cambridge, MA, USA). The length of lanes was about $6 \mathrm{~cm}$. The banding patterns were scanned with a laser densitometer (OneScanner, Apple Computers, Cupertino, CA, USA) and analyzed by using various programs of the Taxotron ${ }^{\otimes}$ package (Taxolab, Institut Pasteur, Paris, France). The TIFF (tagged image file format) image was searched for lanes and bands using RestrictoScan yielding migration data. Fragments sizes were interpolated from migration data using RestrictoTyper implementing the algorithm of Schaffer \& Sederoff (1981). RestrictoTyper compared pairs of patterns and calculated a distance coefficient which was the complement of the Dice index. We chose to set a fixed value of $4 \%$, indicating that 2 fragments were considered identical if their sizes did not differ by more than $4 \%$. A distance matrix was generated for the patterns obtained with each of the primers OPH 06 and $\mathrm{OPH} 08$. These distance matrices were averaged using the program Adanson and treated by the Unweighted Pair Group Method of Averages (UPGMA) (Sneath \& Sokal 1973). The program generated a tree description file which was used by the program Dendrograf to draw a dendrogram and produce an order file. The order file was used by RestrictoTyper to reorder the fragment sizes files and produce a schematic representation of the patterns. The dendrogram and the schematic graph were assembled in a single picture by using a drawing program.

\section{RESULTS}

An initial screening was carried out by testing the 40 primers on 7 representative Flavobacterium psychrophilum isolates. Twenty-eight primers produced clear and reproducible banding patterns, 11 of them yielding polymorphic fragments. Among these, we arbitrarily selected 6 primers for further analysis of isolates: 5 of them (OPH 06, OPH 08, OPG 08, OPG 14, $O P G$ 16) generated different patterns among the 177 strains while the last one (OPG 10) produced an identical pattern for the 35 strains tested. Among the 177 strains in our collection, 60 strains representing the variety in geographical origin and fish host were then selected for high-resolution electrophoresis of their amplification products and computer-assisted analysis 
of their DNA fingerprints. Of these, 36 represented all strains originating from fish species other than rainbow trout which were included in the whole collection. The remaining 24 strains were part of the 141 rainbow trout isolates, and originated from Europe, the USA, and Japan (17 strains, 6 strains, and 1 strain, respectively). RAPD profiles were highly reproducible when analyses were repeated, except for some variations in the intensity of a few faint PCR products.

\section{Differentiation among Flavobacterium psychrophilum strains}

The primer OPG 08 generated 3 different profiles. One was restricted to 1 tench isolate and another one grouped the 4 ayu isolates, while the last profile was common to all other strains. The primer OPG 14 yielded 2 distinct profiles, one grouping 12 rainbow trout isolates and the other common to all other strains tested. Seven different profiles were obtained with the primer OPG 16 (Fig. 1). All rainbow trout isolates exhibited the same profile except the strain JIP 02/86. The coho salmon isolates were divided into 2 profiles, except the strain OSU TM3.1, which displayed another profile in common with the strains isolated from Atlantic salmon, ayu, carp, tench, and steelhead trout. The European eel and cutthroat trout isolates both exhibited unique profiles.

The computer analysis of the combined schematic representations of the fingerprints obtained with the primers OPH 06 and OPH 08 generated the dendrogram presented in Fig. 2. When the primer OPH 06 was used, all isolates tested displayed 4 fragments ( 3 of them very close to one another) within the otherwise heterogeneous fingerprints. Another major fragment

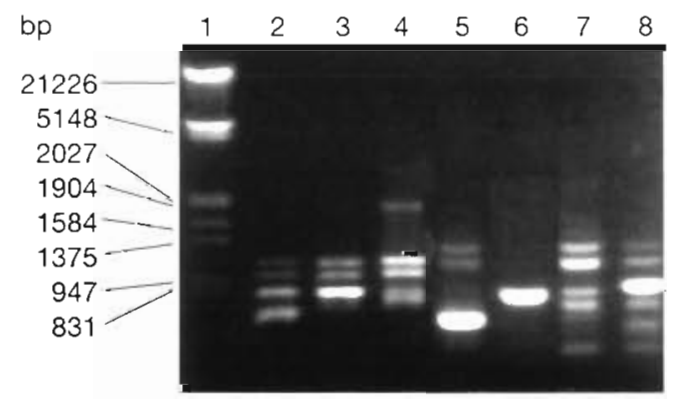

Fig. 1 Flavobacterium psychrophilum. Seven different profiles detected among strains by RAPD with primer OPG 16 . Lanes: $1, E c o$ R I and Hind III digested $\lambda$ DNA molecular weight marker; 2 , rainbow trout isolate JIP 02/86; 3 , rainbow trout isolate JIP P02/88; 4 , cutthroat trout isolate OSU CCC686 ; 5 , coho salmon isolate NCIMB $1947^{\mathrm{T}}$; 6 , coho salmon isolate OSU BC3-81; 7, Atlantic salmon isolate DPIF 91/4043-13; 8, European eel isolate LFNW 131/89 was present in 51 out of 60 OPH 08 profiles. The 4 Japanese strains isolated from ayu were grouped in a very distinct cluster, characterized by the absence of a major OPH 08 fragment (2100 bp) and by the presence of a unique OPH 06 fragment $(1350 \mathrm{bp})$. The 5 Tasmanian Atlantic salmon isolates formed a tight cluster, while the American strain OSU AD10.1.1, originating from the same fish species, grouped with several coho salmon isolates. The coho salmon isolates were separated into 2 major clusters, with the exception of the strain OSU TM3.1, which occupied a rather isolated position in the dendrogram. This distribution of the coho salmon isolates was identical with that obtained with the primer OPG 16. Four coho isolates ( 3 from Chile and 1 from Canada) not included in the computer analysis displayed a fingerprint similar to that of the cluster which included the type strain NCIMB 1947. Of 24 rainbow trout isolates, 22 exhibited the same combined profile, including the strain JIP 02/86, which was differentiated by the primer OPG 16. The lack of the major 2100 bp fragment in the OPH 08 profile clearly differentiated the strains SVA $120-89$ and LVDL 1829 91 , but they were grouped with all other rainbow trout isolates when the primer OPG 16 was used. The primers OPH 06, OPH 08, and OPG 16 thus demonstrated the overall very high homogeneity of the strains isolated from this fish species. The only strain isolated from chinook salmon (OSU SRChF8-81) belonged to 1 of the coho salmon clusters, while the strains originating from cuthroat (OSU CCC6-86) and steelhead (OSU RbS6-82) trout occupied more isolated positions. Concerning the strains isolated from non-salmonid fish, the only strain from European eel (LFNW 131/89) grouped together with most rainbow trout isolates while the 3 strains from tench (LVDJ D2172, LVDJ XP 189, and LFNW 25/90) as well as the 2 strains from carp (LFNW 16/90 and LVDI 5/1) each exhibited distinct profiles, often characterized by the presence of unique fragments.

\section{Differentiation of Flavobacterium psychrophilum from other valid Flavobacterium species}

RAPD patterns obtained with the primer OPG 10 for strains and species in the genus Flavobacterium are shown in Fig. 3. The 35 F. psychrophilum strains tested exhibited the same profile, clearly different from all profiles obtained with the strains representing the 9 other valid Flavobacterium species (Table 2). Several strains of $F$. branchiophilum, F. columnare, F. johnsoniae, and F. succinicans were tested. RAPD with OPG 10 generated different profiles for each strain of the last 3 species (Fig. 3), demonstrating that this primer is also able to differentiate strains among them. 


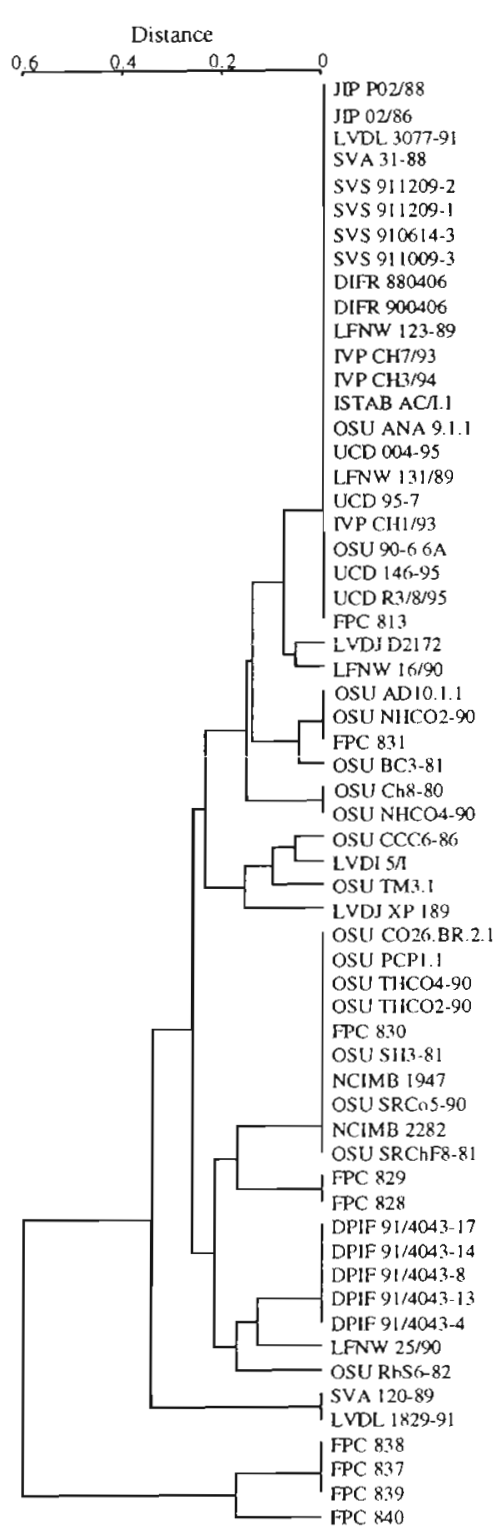

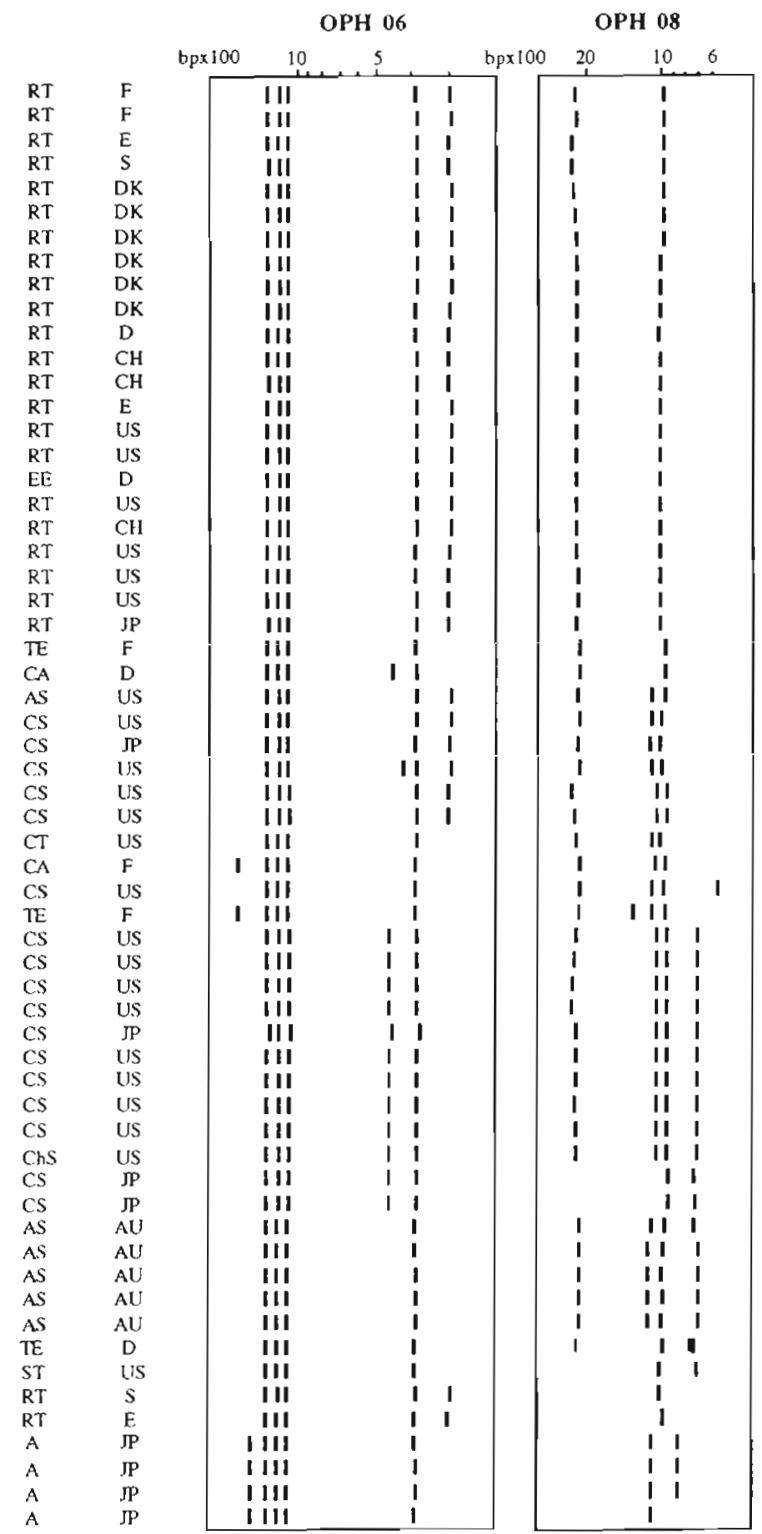

Fig. 2. Flavobacterium psychrophilum. Schematic representation of the RAPD profiles generated by the primers OPI 06 and $O P H$ 08 for 60 isolates and the corresponding dendrogram produced by Dendrograf, a computer program belonging to the Taxotron ${ }^{\otimes}$ software package (Institut Pasteur, Paris) which uses the complement of Dice similarity coefficients. A fragment length tolerance of $4 \%$ and average linkage were used. RT: rainbow trout; EE: European eeli TE: tench; CA: carp; AS: Atlantic salmon; CS: coho salmon; CT: cutthroat trout ChS: chinook salmon; ST: steelhead trout ${ }_{i} A:$ ayu. F: France; E: Spain; S: Sweden; DK: Denmark; D: Germany; $\mathrm{CH}$ : Switzerland; US: USA; JP: Japan; AU: Australia

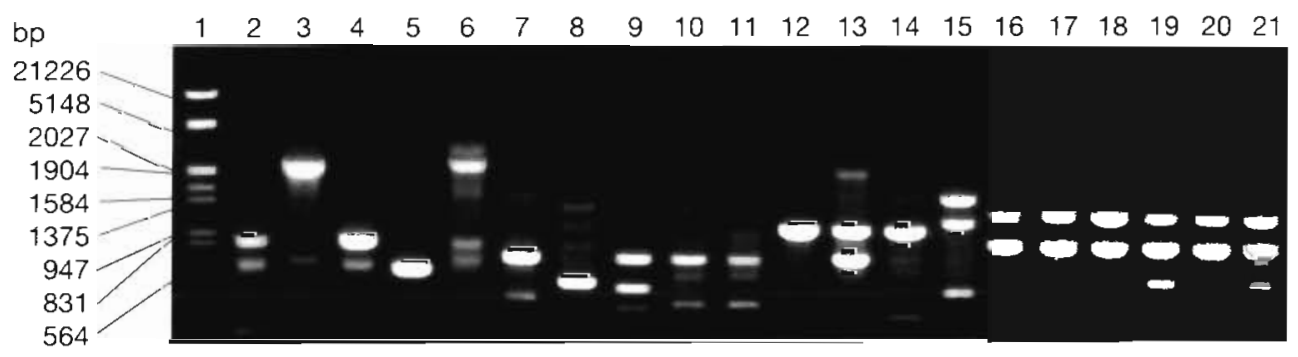

Fig. 3. Flavobacterium spp. Different profiles detected among strains belonging to the 10 valid Flavobacterium species as determined by RAPD with the primer OPG 10. Lanes: 1, ECoR I and Hind III digested $\lambda$ DNA molecular weight marker; $2, F$. johnsoniae DSM $2064^{\mathrm{T}} ; 3$, F johnsoniae ATCC 29585; 4, F. succinicans NCIMB $2277^{\mathrm{T}} ; 5$, F. succinicans NCIMB 2278; $6, F$. hydatis DSM 2063 ${ }^{\mathrm{T}}$; 7. F. saccharophilum NCIMB $2072^{\mathrm{T}}$; 8, F pectinovorum NCIMB $9059^{\mathrm{T}} ; 9, F$ aquatile LMG $4008^{\mathrm{T}} ; 10$, F. branchiophilum ATCC $35035^{\top} ; 11, F$. branchiophilum FL-15; 12, F. columnare JIP 39/87; 13, F. columnare FPC EK28; 14, F. columnare OSU DD3-69; 15, F. flevense DSM $1076^{\mathrm{T}} ; 16, F$. psychrophilum NCIMB $1947^{\mathrm{T}} ; 17, F$. psychrophilum JIP P02/88; 18, F. psychrophilum LVDJ XP 189; 19, F. psychrophilum OSU CCC6-86; 20, F. psychrophilum FPC 839; 21, F. psychrophilum OSU RbS6-82 


\section{DISCUSSION}

This study was undertaken in order to determine whether random amplification by PCR would allow a differentiation among Flavobacterium psychrophilum isolates and/or between F. psychrophilum and other Flavobacterium species. Our results showed that both kinds of differentiation could indeed be achieved.

In this study, the primers OPH 06 and $O P H 08$ produced several different amplification profiles among a collection of 177 Flavobacterium psychrophilum isolates. Most geographical origins and all fish hosts were represented among the 60 strains selected for computer-assisted analysis of their resolutive electrophoresis profiles. This selection also included representatives of all different RAPD profiles detected by visual observation of rapid electrophoresis gels. No clear association could be detected between the combined patterns generated by the 2 primers and the geographical origin of the isolates, while a strong correlation occurred between some patterns and the fish host (Fig. 2).

This correlation was particularly clear in the case of the strains isolated from rainbow trout, probably because many strains were included in this study compared to the limited number of strains originating from other fish species. All rainbow trout isolates exhibited the same combined pattern whatever their geographical origin (California, Idaho, Oregon, USA; Japan; France; Spain; Sweden; Denmark; Germany; and Switzerland) with the exception of the strains SVA $120-$ 89 and LVDL 1829-91 (originating from Sweden and Spain, respectively), whose patterns differed by the deletion of a major $\mathrm{OPH} 08$ fragment. The fingerprints of 117 other rainbow trout isolates were compared by visual observation. When only part of the strains originating from a given country were studied by computer analysis, the other strains from the same origin were found to display the same profile. The strains isolated from trout in countries not represented among the 60 selected strains (i.e. the 2 strains from Chile, the 6 strains from the United Kingdom, the single strain from Norway, and the 1 strain from Finland) also exhibited the typical rainbow trout fingerprint. The presence of the same RAPD fingerprint among rainbow trout isolates from widely different geographical areas may be related to the long-standing international trade of rainbow trout eggs and broodfish. Vertical transmission of the disease has long been suspected. The presence of Flavobacterium psychrophilum in the coelomic fluid and in milt was demonstrated a decade ago (Holt 1987 ), but it is only recently that its presence within the egg was confirmed (Brown et al. 1997).

The 4 ayu isolates from Japan were clearly distinguished from all other strains studied by 3 different primers (i.e. OPH 06, OPH 08, and OPG 08) whereas the 2 Japanese strains isolated from rainbow trout (only 1 was included in the computer analysis) and the 4 coho salmon isolates shared common profiles with the strains from the same fish hosts in other countries. Coho salmon and rainbow trout presently cultured in Japan all originate from the USA. Ten thousand rainbow trout eggs were first introduced from California in 1877 and lesser numbers have been occasionally imported since then; large numbers of coho salmon eggs have been imported every year from the Pacific coast of the USA (and to a much smaller extent from Canada and Chile) since their first introduction in 1975 (Wakabayashi 1996). The first outbreaks of cold-water disease in coho and ayu occurred in Japan during the mid-eighties. Interestingly, the first European outbreaks were noticed at about the same time in rainbow trout reared in Germany (Weis 1987) and in France (Bernardet et al. 1988), although this fish species was introduced in Europe during the last quarter of the nineteenth century. There is no evidence that Flavobacterium psychrophilum existed in Japan before coho salmon and rainbow trout were introduced (H. Wakabayashi pers. comm.), although this hypothesis cannot be definitely dismissed. Therefore, it is likely that $F$. psychrophilum was introduced in Japan with infected trout or salmon eggs from the USA. The passage of the pathogen to ayu may somehow have induced a genetic modification resulting in a change in RAPD profiles. It is also possible that local bacterial strains exhibiting a particular RAPD profile indeed existed in Japan before new strains were introduced from the USA. They may have escaped detection as long as they infected wild ayu at a very low prevalence but they progressively came to induce epizootics through the intensification of ayu farming.

Few examples have been published of such a correlation between DNA fingerprints of bacteria and the animal or plant species from which they had been isolated. Different RAPD patterns were indeed displayed by Porphyromonas gingivalis strains isolated from humans and animals (Ménard \& Mouton 1993), as well as by Campylobacter jejuni and Campylobacter coli strains isolated from poultry and other animal sources (Aarts et al. 1995), but the authors proposed no convincing explanation. Isolates of the plant pathogen Xylella fastidiosa were clearly differentiated by RAPD according to the species of plant from which they were isolated (Chen et al. 1995). These authors suggested that RAPD could be used to define pathotypes or subspecies among bacterial species. Several RAPD primers did not differentiate Vibrio anguillarum strains belonging to different serotypes and isolated from various fish species, but only a few strains were included in the study (Martinez et al. 1994). When RAPD profiles generated by 2 primers among 36 Aeromonas salmonicida 
isolates were compared, 'no geographic, mutual or fish species associated types were found' (Hänninen et al. 1995)

Different typing methods other than RAPD have been proposed to compare Flavobacterium psychrophilum strains among themselves: serologic analysis (Lorenzen 1994, Wakabayashi et al. 1994); genetic analysis based on plasmid profile (Holt 1987, Lorenzen 1994) or rRNA gene restriction pattern (ribotype) (Cipriano et al. 1996); and electrophoretic pattern of proteases (Bertolini et al. 1994). Although no association could be found between fish host and either ribotype or plasmid profile, some correlation between fish host and serotype did appear in the results published by Wakabayashi et al. (1994). Two serotypes were revealed by the absorption analysis with heat-stable antigens. The serotype $\mathrm{O}-1$ was common to all American and Japanese cono isolates, whereas the ayu isolates as well as the strains isolated from rainbow trout in Japan belonged to the serotype O-2 (Wakabayashi et al. 1994). These data parallel the results of our study and support the hypothesis of the American origin of the strains isolated from coho salmon in Japan. However, the question of the origin of the serotype and RAPD profiles specific to the strains isolated from ayu remains unanswered.

Comparison of our data with the protease patterns is also interesting since 20 Flavobacterium psychrophilum isolates among the 29 studied by Bertolini et al. (1994) were also included in our study. According to these authors, the 29 isolates were divided into 4 groups based on the presence or absence of certain proteases visualized by substrate sodium dodecyl sulphate polyacrylamide gel electrophoresis (SDS-PAGE). A correlation was found between protease groups and fish hosts, as all 11 isolates in protease group 1 originated from coho salmon whereas all 12 isolates from other fish species belonged to protease groups 2, 3 and 4. The authors tested the virulence of representatives of each protease group in juvenile coho salmon. Some association was noticed between protease group and virulence, as most group 1 strains induced a high mortality and isolates belonging to other protease groups tended to be less pathogenic. In our study, all strains in Bertolini's protease group 1 belonged to the cluster which included the type strain whereas most strains in protease group 2 belonged to the other coho salmon cluster. Therefore, a correlation seems to exist between fish host, proteolytic activity, RAPD profile, and virulence, suggesting that several pathotypes may exist among $F$. psychrophilum isolates. However, the high virulence of protease group 1 strains was also demonstrated by Bertolini et al. (1994) on steelhead trout and 6.5 to $12 \%$ mortality also occurred when 3 groups of 25 steelhead trout were each injected sub- cutaneously with a different ayu isolate. Similarly, Holt (1987) was able to induce severe mortality in yearling coho salmon after subcutaneous injection of $F$. psychrophilum strains isolated from coho, chinook and chum salmons, but no mortality occurred when coho salmon were injected with isolates from rainbow, brook, cutthroat and steelhead trout. In the same study some isolates from coho salmon also failed to induce any mortality. These results demonstrated that the virulence of $F$. psychrophilum isolates is not restricted to the species or to the genus of fish from which the strains were isolated. Actually, the correlation noticed by Bertolini et al. (1994) was not absolute, as 5 highly virulent coho salmon isolates belonged to the protease group 2. The virulence of $F$. psychrophilum may thus involve other mechanisms in addition to proteolytic activity, as already suggested by these authors (Bertolini et aì. i 994).

The only European eel isolate included in our study (LFNW 131/89) fell within the cluster grouping most rainbow trout isolates, among others the strain LFNW $123 / 89$ isolated from the same river in Germany and during the same outbreak (Lehmann et al. 1991), suggesting that the eel was infected by a strain originating from a rainbow trout. However, the primer OPG 16 was able to differentiate the eel isolate from all trout isolates (Fig. 1). Furthermore, the strains LFNW 16/90 and LFNW 25/90, also isolated during the same outbreak from a carp and a tench, respectively, each displayed profiles different from the typical rainbow trout pattern. Hence, Flavobacterium psychrophilum strains exhibiting different RAPD profiles may coexist in the course of an epizootic, but more strains should be studied in order to verify the apparent correlation with fish host noticed during the German outbreak.

A rather similar situation was found among the strains isolated in Oregon and neighbouring states. Various RAPD profiles were found among Flavobacterium psychrophilum strains retrieved from hatcheries belonging to 2 main groups (i.e. the lower Columbia River hatcheries and the coastal hatcheries). Over the years, many transfers of fish occurred between the hatcheries within each group, as well as much less frequent transfers between the 2 groups. Moreover, most hatcheries raise a variety of fish species such as coho and chinook salmon as well as rainbow and steelhead trout, and straying of adult fish is known to occur (R. A. Holt pers. comm.). The 2 strains isolated from chinook (OSU SRChF8-81) and Atlantic (OSU AD10.1.1) salmon were grouped together with the coho isolates and may thus originate from coho salmon reared in the same region. Indeed, the chinook isolate was retrieved from the same fish farm at which the strain OSU SRCo5-90 was isolated from coho and both strains displayed identical profiles. However, the 2 strains from 
steelhead (OSU RbS6-82) and cutthroat (OSU CCC686) trout, also from Oregon, exhibited very distinct profiles. Thus, different RAPD profiles have been shown to occur within a region where natural and artificial transfers of fish are very frequent, and it is not clear why coho salmon isolates are divided into 2 clusters.

No conclusion could be drawn from the very homogeneous profile displayed by the 5 Tasmanian Atlantic salmon isolates, since they were all retrieved at the same time from the same fish farm and the only other Atlantic salmon isolate included in the study grouped together with coho isolates. Moreover, no strain isolated from other fish species in Tasmania was available.

Many Gram-negative yellow pigmented bacteria, several Flavobacterium species among them, coexist in freshwater environments and may occasionally be isolated from sick or healthy fish. Because most of these bacteria have a fastidious growth and are inert in many biochemical tests, contamination and erroneous identification may occur. Our study demonstrated that a rapid and accurate identification of $F$. psychrophilum as well as its differentiation from related species could be achieved through RAPD using the primer OPG 10 because species-specific products were amplified. Identification of $F$. psychrophilum with this technique is even possible using a single colony collected from a mixed culture on an agar plate (data not shown). Several bacterial species have also been differentiated from closely related species using particular RAPD primers. Examples among fish-pathogenic bacteria include primers generating fingerprints which clearly differentiated Vibrio salmonicida, $V$. anguillarum, and $V$. fisheri (Martinez et al. 1994) as well as different Aeromonas species isolated from fish (Miyata et al. 1995) or from widely different clinical and environmental sources (Oakey et al. 1996).

Because very few template DNA and no previous knowledge of nucleotide sequence are required, and because the whole genome is analyzed (Oakey et al. 1996), RAPD has several advantages over the other techniques that have been used alone or in various combinations for identifying Flavobacterium psychrophilum, such as phenotypical investigations (Holt 1987), DNA/DNA hybridization (Bernardet \& Grimont 1989), serological tests revealing specific antigens (Pacha 1968, Holt 1987, Cipriano et al. 1996), wholecell protein (Bernardet et al. 1996, Cipriano et al. 1996) or fatty acid analyses (Bernardet et al. 1996), and $16 \mathrm{~S}$ rDNA-targeted PCR (Toyama et al. 1994). DNA/DNA hybridization is the reference technique for determining whether 2 bacterial strains belong to the same species (Wayne et al. 1987), but its use is restricted to the laboratories involved in taxonomical and phyloge- netic studies. Phenotypic, biochemical, and serological methods of identification are usually cumbersome and time-consuming because $F$. psychrophilum is relatively fastidious and because antisera or bacterial extracts have to be prepared.

This study provides a powerful method for an efficient typing of Flavobacterium psychrophilum strains for epidemiological tracing. It also allows a reliable differentiation of F. psychrophilum from phylogenetically related bacterial species coexisting in the same environment. Until now, ribotyping was considered the only molecular typing method able to provide both identification and typing potentials (Brosch et al. 1996); it is now clear that RAPD profiles also carry both kinds of information.

Acknowledgements. The authors are indebted to the individuals who kindly provided bacterial strains. In addition to those already cited in the footnotes of Tables 1 \& 2, we thank M. Vigneulle (Laboratoire de Pathologie des Animaux Aquatiques, Centre National d'Etudes Vétérinaires et Alimentaires, Plouzané, France), R. Le Goas (Laboratoire Vétérinaire Départemental de Seine Maritime, Rouen, France), M. Schaumburg (Veterinäruntersuchungsamt Mittelhessen, Giessen, Germany), D. Bruno (Marine Laboratory, Aberdeen, Scotland. UK), A. Toranzo and J. Barja (Departamento de Microbiología y Parasitologia, Facultad de Biología, Universidad de Santiago de Compostela, Spain), S. Høie (Central Veterinary Laboratory, Oslo, Norway), R. Enríques (Unidad de Ictiopatología, Universidad Austral de Chile, Valdivia, Chile), J. Montana (Servicio de Ictiopatología, Fundación Chile, Puerto Montt, Chile), and V. Hirvelä-Koski (National Veterinary and Food Research Institute, Oulu Regional Laboratory, Oulu, Finland). We are grateful to P. Tailliez (Recherches Laitières, Institut National de la Recherche Agronomique, Jouy-en-Josas, Francel as well as to E. ChaslusDancla, S. Leroy-Sétrin, and M.-C Lesage-Descauses (Laboratoire d'Ecopathologie Microbienne, Institut National de la Recherche Agronomique, Nouzilly, France) for kind advice about the use of RAPD. C. Bizet and C. Barreau (Collection de Bactéries de l'Institut Pasteur, Paris, France) are acknowledged for kind help with the data analysis. Our manuscript benefited from detailed and helpful information about the local epidemiology of cold-water disease provided by $\mathrm{H}$. Wakabayashi (Laboratory of Aquaculture Biology, University of Tokyo, Japan) and by R. A. Holt (Department of Microbiology, Oregon State University, Corvallis, Oregon). C.C. thanks the French Ministery of Foreign Aaffairs for a research grant.

\section{LITERATURE CITED}

Aarts HJM, Van Lith LAJT, Jacobs-Reitsma WF (1995) Discrepancy between Penner serotyping and polymerase chain reaction fingerprinting of Campylobacter isolated from poultry and other animal sources. Lett Appl Microbiol 20:371-374

Anacker RL, Ordal EJ (1955) Study of a bacteriophage infecting the myxobacterium Chondrococcus columnaris. J Bacteriol 70:738-741

Anderson JIW, Conroy DA (1969) The pathogenic myxobacteria with special reference to fish diseases. J Appl Bacteriol $32: 30-39$ 
Austin B (1992) The recovery of Cytophaga psychrophila from two cases of rainbow trout (Oncorhynchus mykiss Walbaum) fry syndrome in the UK. Bull Eur Assoc Fish Pathol 12:207-208

Bernardet JF, Baudin-Laurencin F, Tixerant G (1988) First identification of Cytophaga psychrophila in France. Bull Eur Assoc Fish Pathol 8:104-105

Bernardet JF, Grimont PAD (1989). Deoxyribonucleic acid relatedness and phenotypic characterization of Flexibacter columnaris sp. nov., nom. rev., Flexibacter psychrophilus sp. nov., nom. rev., and Flexibacter maritimus Wakabayashi, Hikida, and Masumura 1986. Int J Syst Bacteriol 39:346-354

Bernardet JF, Segers P, Vancanneyt M, Berthe F, Kersters $K$, Vandamme P (1996) Cutting a Gordian knot: emended classification and description of the genus Flavobacterium, emended description of the family Flavobacteriaceae, and proposal of Flavobacterium hydatis nom. nov. (basonym, Cytophaga aquatilis Strohl and Tait 1978). Int J Syst Bacteriol 46:128-148

Bertolini JM, Wakabayashi H, Watral VG, Whipple MJ, Rohovec JS (1994) Electrophoretic detection of proteases from selected strains of Flexibacter psychrophilus and assessment of their variability. J Aquat Anim Health 6:224-233

Borg AF (1960) Studies on myxobacteria associated with diseases in salmonid fishes. American Association for the Advancement of Science, Wildlife Disease, no. 8, Washington, DC

Brosch R, Lefèvre M, Grimont F, Grimont PAD (1996) Taxonomic diversity of pseudomonads revealed by computer interpretation of ribotyping data. Syst Appl Microbiol 19: $541-555$

Brown LL, Cox WT, Levine RP (1997) Evidence that the causal agent of bacterial cold-water disease Flavobacterium psychrophilum is transmitted within salmonid eggs. Dis Aquat Org 29:213-218

Bustos PA, Calbuyahue J, Montaña J, Opazo B, Entrala P, Solervicens R (1995) First isolation of Flexibacter psychrophilus as causative agent of rainbow trout fry syndrome (RTFS), producing rainbow trout mortality in Chile Bull Eur Assos Fish Pathol 15:162-164

Chen J, Lamikandra O, Chang CJ, Hopkins DL (1995) Randomly amplified polymorphic DNA analysis of Xylella fastidiosa Pierce's disease and oak leaf scorch pathotypes Appl Environ Microbiol 61:1688-1690

Cipriano RC, Schill WB, Teska JD, Ford LA (1996) Epizootiological study of bacterial cold-water disease in Pacific salmon and further characterization of the etiologic agent, Flexibacter psychrophila (sic). J Aquat Anim Health 8: $28-36$

Hänninen ML, Ridell J, Hirvelä-Koski V (1995). Phenotypic and molecular characteristics of Aeromonas salmonicida subsp. salmonicida isolated in Southern and Northern Finland. J Appl Bacteriol 79:12-21

Holt RA (1987) Cytophaga psychrophila, the causative agent of bacterial cold-water disease in salmonid fish. PhD thesis, Oregon State University, Corvallis

Lehmann J, Mock D. Stürenberg FJ, Bernardet JF (1991) First isolation of Cytophaga psychrophila from a systemic disease in eel and cyprinids. Dis Aquat Org 10:217-220

Lorenzen E (1994) Studies on Flexibacter psychrophilus in relation to rainbow trout fry syndrome (RTFS). PhD thesis, National Veterinarian Laboratory Århus and Royal Veteri- nary and Agriculture University, Copenhagen, Denmark Lorenzen E, Dalsgaard I. From J, Hansen EM, Horlyck V, Korsholm H, Mellergaard S, Olsen NJ (1991) Preliminary investigations of fry mortality syndrome in rainbow trout Bull Eur Assoc Fish Pathol 11:77-79

Martinez I, Espelid S, Johansen A, Welsh J, McClelland M (1994) Fast identification of species and strains of Vibrio by amplification of polymorphic DNA. J Fish Dis 17 297-302

Ménard C, Mouton C (1993) Randomly amplified polymorphic DNA analysis confirms the biotyping scheme of Porphyromonas gingivalis. Res Microbiol 144:445-455

Meunier JR, Grimont PAD (1993) Factors affecting reproducibility of random amplified polymorphic DNA fingerprinting. Res Microbiol 144:373-379

Miyata M, Aoki T, Inglis V, Yoshida T, Endo M (1995) RAPD analysis of Aeromonas salmonicida and Aeromonas hydrophila. J Appl Bacteriol 79:181-185

Oakey HJ, Ellis JT, Gibson LF (1996) Differentiation of Aeromonas genomospecies using random amplified polymorphic DNA polymerase chain reaction (RAPD- PCR). J Appl Bacteriol 80:402-410

Pacha RE (1968) Characteristics of Cytophaga psychrophila (Borg) isolated during outbreaks of bacterial coldwater disease. Appl Microbiol 16:97-101

Sarti M, Giorgetti G, Manfrin A (1992) Method for the rapid diagnosis of visceral myxobacteriosis in reared trout in Italy. Bull Eur Assoc Fish Pathol 12:53

Schaffer HE, Sederoff RR (1981) Improved estimation of DNA fragments lengths from agarose gels. Anal Biochem 115: $113-122$

Schmidtke LM, Carson J (1995) Characteristics of Flexibacter psychrophilus isolated from Atlantic salmon in Australia Dis Aquat Org 21:157-161

Sneath PHA, Sokal RR (1973) Numerical taxonomy. WH Freeman, San Francisco

Toranzo AE, Barja JL (1993) Fry mortality syndrome (FMS) in Spain. Isolation of the causative bacterium Flexibacter psychrophilus. Bull Eur Assoc Fish Pathol 13:30-32

Toyama T, Kita-Tsukamoto K, Wakabayashi H (1994) Identification of Cytophaga psychrophila by PCR targeted I6S ribosomal RNA. Fish Pathol 29:271_-275

Wakabayashi $H$ (1996) Importation of aquaculture seedlings to Japan. Rev Sci Tech Off Int Epizoot 15:409-422

Wakabayashi $H$, Toyama $T$, lida $T$ (1994) A study on serotyping of Cytophaga psychrophila isolated from fishes in Japan. Fish Pathol 29:101-104

Wayne LG, Brenner DJ, Colwell RR, Grimont PAD, Kandler O. Krichevsky MI, Moore LH, Moore WEC, Murray RGE Stackebrandt E, Starr MP, Trüper HG (1987) Report of the ad hoc committee on reconciliation of approaches to bacterial systematics. Int J Syst Bacteriol 37:463-464

Weis von J (1987) Über das Vorkommen einer Kaltwasserkrankheit bei Regenbogenforellen, Salmo gairdneri. Tierärztl Umsch 42:575-577

Wiklund T, Kaas K, Lömström L, Dalsgaard I (1994) Isolation of Cytophaga psychrophila (Flexibacter psychrophilus) from wild and farmed rainbow trout (Oncorhynchus mykiss) in Finland. Bull Eur Assoc Fish Pathol 14:44-46

Williams JGK, Kubelik AR, Livak KJ, Rafalski JA, Tingey SV (1990) DNA polymorphisms amplified by arbitrary primers are useful as genetic markers. Nucleic Acids Res 18: $6531-6535$

Submitted: August 27, 1997; Accepted: November 10, 1997 Proofs received from author(s): December 22, 1997 